\title{
-megasains
}

\section{Variasi Suhu Udara, Suhu Titik Embun, Dan Tekanan Udara Terhadap Gaya Angkat Pesawat Di Bandara Supadio Pontianak Tahun 2016}

\author{
I Dewa Gede Arya Putra ${ }^{1}$ dan Yusuf Hadi Perdana ${ }^{1}$ \\ ${ }^{1}$ Puslitbang BMKG, Jl. Angkasa 1 No.2 Kemayoran Jakarta, 10720
}

\begin{abstract}
Abstrak. Cuaca memiliki peran sangat penting terhadap efisiensi penerbangan. Kerapatan udara rendah membuat pesawat membutuhkan landasan pacu yang panjang ketika lepas landas. Hal tersebut dapat meningkatkan beban kerja mesin untuk menambah kecepatannya di runway. Kondisi atmosfer selalu dinamis dan tidak dapat dikendalikan. Pesawat harus mendapatkan gaya angkat maksimal dengan memperhitungkan kondisi tertentu. Operator penerbangan hanya dapat menyesuaikan dengan kondisi meteorologi tersebut untuk memperhitungkan efisiensi penerbangan. Penelitian ini dilakukan di Bandara Supadio Pontianak menggunakan data observasi Stasiun Meteorologi Supadio Pontianak tahun 2016. Data yang digunakan meliputi meliputi suhu udara, suhu titik embun, dan tekanan udara. Berdasarkan hasil perhitungan didapatkan bahwa suhu udara memiliki pengaruh yang paling signifikan terhadap gaya angkat pesawat. Gaya angkat maksimum harian terjadi sekitar pukul 05.00 - 06.00 WIB dan gaya angkat minimum terjadi sekitar pukul 13.00 - 14.00 WIB. Gaya angkat terbesar bulanan terjadi pada bulan Januari dan terkecil pada bulan Agustus.
\end{abstract}

(Kata kunci: Gaya angkat, kerapatan udara, lepas landas)

Abstract. Weather plays the significant role on
aviation efficiency. The low air density makes
longer runway for aircraft to take off. The
atmosphere condition changes dynamically and
it can not be handled. Aircrafts have to get the
maximum lifting force regarded to certain
conditions. The aviation operators adjust the
meteorological condition to calculate the
efficiency of aviation. This research was done
on Supadio Pontianak Airport using observation
of Supadio Pontianak Meteorology Station
during 2016. The data consists of air
temperature, dew point temperature, and air pressure. Based on the calculations, it is known that air temperature have the highest influence to lifting force of aircrafts. The maximum lifting force diurnal happened around 05.00 - 06.00 am and the minimum lifting force happened around $01.00-02.00 \mathrm{pm}$. The highest monthly lifting force happened on January and the minimum lifting force happened on August.

(Keywords: lifting force, air density, take off)

\section{Pendahuluan}

Cuaca memiliki peran sangat penting terhadap efisiensi penerbangan. Unsur cuaca cukup signifikan mempengaruhi kinerja pesawat terbang. Kinerja pesawat terbang bergantung pada kerapatan udara yang secara langsung mempengaruhi lift (gaya angkat) $[1,2,3]$. Performa optimum pesawat terbang akan menurun bila kerapatan udara semakin berkurang. Tekanan udara rendah dan suhu udara tinggi akan membuat kerapatan udara rendah. Take off (lepas landas) dengan kondisi kerapatan udara rendah mengakibatkan bertambahnya landasan pacu yang digunakan dan meningkatkan beban kerja mesin karena dalam kondisi ini kecepatan pesawat di runway harus ditambah $[4,5,6]$.

Kondisi atmosfer selalu dinamis dan tidak dapat dikendalikan. Operator penerbangan hanya dapat menyesuaikan dengan kondisi meteorologi untuk memperhitungkan efisiensi penerbangan $[7,8,9]$. Untuk mengefisiensi penerbangan maka pesawat harus mendapatkan gaya angkat maksimal dengan memperhitungkan kondisi tertentu. Tujuan penulisan ini adalah mengetahui pengaruh cuaca dari unsur suhu udara, suhu titik embun, dan tekanan udara terhadap gaya angkat pesawat di landasan. Manfaat dari penelitian adalah dapat mengetahui waktu kinerja terbaik pesawat berdasarkan unsur meteorologi setempat, 
sehingga didapatkan kondisi yang terbaik dan efisien untuk lepas landas.

\section{Metode Penelitian}

Penelitian ini dilakukan di Bandara Supadio Pontianak pada koordinat $00^{\circ} 09^{\prime} 2$ 'LU dan $109^{\circ} 24^{\prime} 14$ "BT dengan ketinggian 3 meter di atas permukaan laut. Data yang digunakan adalah data observasi Stasiun Meteorologi Supadio Pontianak selama tahun 2016, meliputi:

- Suhu udara ( $\left.T_{o b s} T_{o b s}\right)$ dari pengukuran termometer air raksa.

- Suhu titik embun $\left(T_{d}\right)$ dari tabel suhu titik embun berdasarkan pengukuran termometer bola basah dan termometer bola kering.

- Tekanan udara $\left.\left(P_{o b s}\right) P_{o b s}\right)$ dari hasil pengukuran barometer digital.

Ketiga data tersebut diamati setiap satu jam dan dicatat dalam formulir ME.48.

Unsur tekanan udara, suhu udara, dan suhu titik embun akan mempengaruhi kerapatan udara di landasan pacu pesawat. Kerapatan udara dapat diketahui menggunakan rumus berikut [10]:

$$
\begin{aligned}
& p p=C_{0}+T_{d}\left(C_{1}+T_{d}\left(C_{2}+T_{d}\left(C_{3}+T_{d}\right.\right.\right. \\
& \left(C_{4}+T_{d}\left(C_{5}+T_{d}\left(C_{6}+T_{d}\left(C_{7}+T_{d}\right.\right.\right.\right. \\
& \left.\left.\left.\left.\left.\left.\left(C_{8}+T_{d}\left(C_{9}\right)\right)\right)\right)\right)\right)\right)\right) \\
& \mathrm{E}_{s}=\frac{e_{s o}}{p^{8}} \\
& P_{d}=P_{o b s}-\mathrm{E}_{s} \\
& \rho=\frac{P_{d}}{R_{d} \times T_{o b s}}+\frac{E_{s}}{R_{v} \times T_{o b s}}
\end{aligned}
$$

Gaya angkat pesawat terbang dihitung secara empiris menggunakan persamaan berikut :

$$
L=\frac{1}{2} \rho \times V^{2} \times C l \times S
$$

Keterangan:

$$
\begin{array}{ll}
e_{s o} e_{s o} & =6.1078 \\
C_{0} & =0.99999683 \\
C_{1} & =-0.90826951 \cdot 10^{-2} \\
C_{2} & =0.78736169 \cdot 10^{-4} \\
C_{3} & =-0.61117958 \cdot 10^{-6} \\
C_{4} & =0.43884187 \cdot 10^{-8} \\
C_{5} & =-0.29883885 \cdot 10^{-10} \\
C_{6} & =0.21874425 \cdot 10^{-12} \\
C_{7} & =-0.17892321 \cdot 10^{-14} \\
C_{8} & =0.11112018 \cdot 10^{-16} \\
C_{9} & =-0.30994571 \cdot 10^{-19} \\
T_{d} & =\text { Suhu titik embun observasi }\left({ }^{\circ} \mathrm{C}\right) \\
P_{o b s} P_{o b s} \quad \quad=\text { Tekanan udara terukur }(\mathrm{hPa}) & \\
\rho \rho & =\text { Kerapatan udara }\left(\mathrm{kg} / \mathrm{m}^{3}\right) \\
P_{d} P_{d} & =\text { Tekanan parsial udara kering }(\mathrm{Pa})
\end{array}
$$

$R_{d} R_{d}=$ Konstanta gas khusus untuk udara kering $287.058 \mathrm{~J} /(\mathrm{kg} \cdot \mathrm{K})$

$T_{o b s} T_{o b s} \quad=$ Suhu udara terukur $(\mathrm{K})$

$E_{s} E_{s} \quad=$ Tekanan uap air $(\mathrm{Pa})$

$R_{v} R_{v}=$ Konstanta gas khusus untuk uap air $461.495 \mathrm{~J} /(\mathrm{kg} \cdot \mathrm{K})$

Spesifikasi Boeing 737-800 NG [3]:

$$
\begin{array}{ll}
L L & =\text { Gaya angkat (Newton) } \\
\rho \rho & =\text { Kerapatan udara }\left(\mathrm{kg} / \mathrm{m}^{3}\right) \\
V V & =\text { Kecepatan aliran udara } 75 \mathrm{~m} / \mathrm{s} \\
\mathrm{ClCl} & =\text { Koefisien lift } 6.4 \mathrm{~s}^{2} / \mathrm{m} \\
S S & =\text { Luas permukaan sayap } 124 \mathrm{~m}^{2}
\end{array}
$$

\section{Hasil dan Pembahasan}

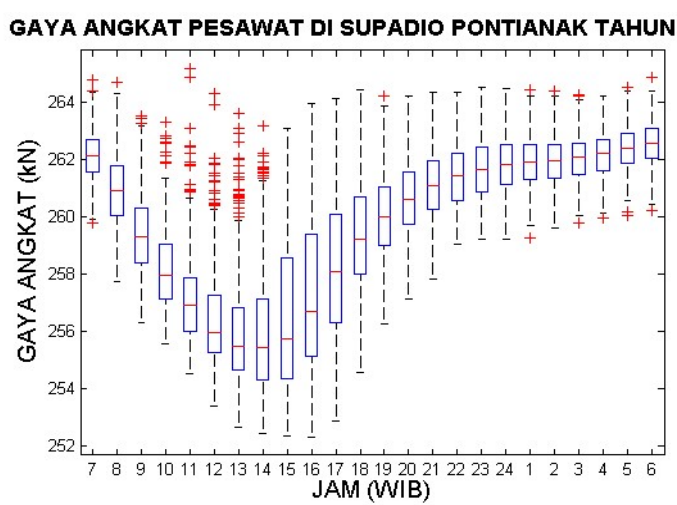

\section{Gambar 1. Boxplot gaya angkat tiap jam selama tahun 2016}

Gaya angkat pesawat harian pada tahun 2016 berkisar antara 252,30 kN hingga 265,16 kN. Berdasarkan Gambar 1, distribusi gaya angkat maksimum terjadi sekitar pukul 05.00 - 06.00 WIB dengan kisaran normal 262,37 - 262,56 kN, sedangkan distribusi gaya angkat minimum terjadi pada pukul 13.00 14.00 WIB dengan kisaran normal 256,01 kN. 

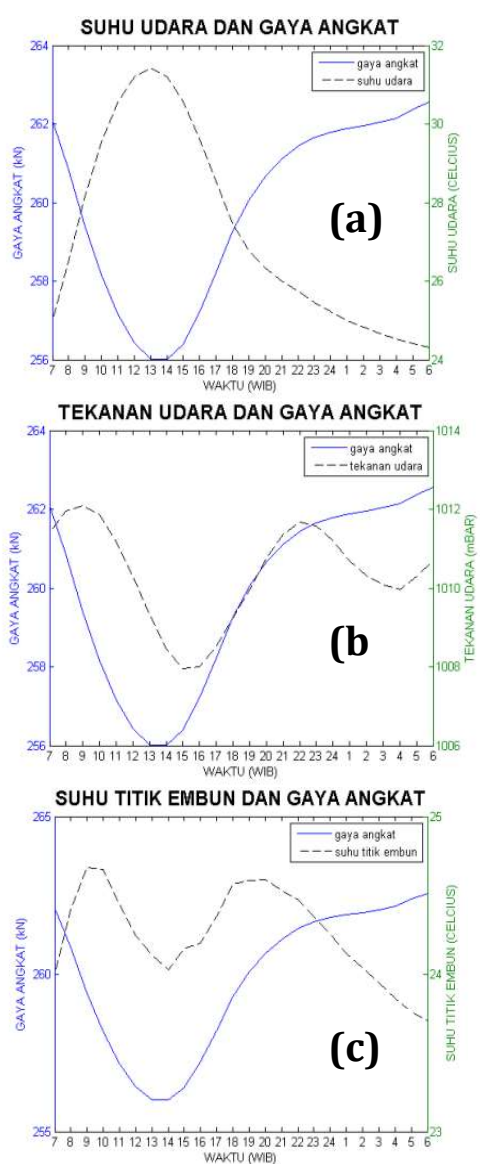

Gambar 2. (a) Pola suhu udara dan gaya angkat, (b) Pola tekanan udara dan gaya angkat, dan (c) Pola suhu titik embun dan gaya angkat

Berdasarkan gambar 2 (a) pola suhu harian berlawanan arah dengan besarnya gaya angkat pesawat. Suhu tertinggi terjadi pada pukul 13.00 WIB - 14.00 WIB yang berpengaruh terhadap penurunan gaya angkat yang minimum pada jam tersebut. Berdasarkan gambar 2 (b) pola tekanan searah dengan pergerakan gaya angkat namun tidak terlalu signifikan. Saat tekanan udara rendah gaya angkat juga minimum yang terjadi sekitar jam 13.00 WIB - 15.00 WIB. Berdasarkan gambar 3 (c) suhu titik embun memiliki pola yang kurang begitu jelas terhadap besarnya gaya angkat pesawat.

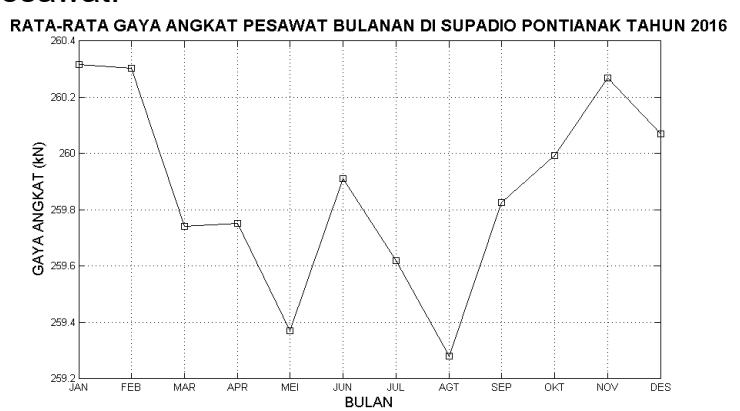

Gambar 3. Rata-rata gaya angkat bulanan selama tahun 2016
Rata-rata gaya angkat pesawat bulanan di tahun 2016 cukup bervariasi. Berdasarkan gambar 1 rata-rata gaya angkat maksimum terjadi pada bulan Januari dengan nilai 260,32 kN dan bulan Februari dengan nilai $260,30 \mathrm{kN}$, sedangkan rata-rata gaya angkat minimum terjadi pada bulan Agustus dengan nilai 259,28 kN dan bulan Mei dengan nilai $259,36 \mathrm{kN}$.

\section{Kesimpulan}

Berdasarkan analisis dan pembahasan yang telah dilakukan, dapat disimpulkan, suhu udara memiliki pengaruh yang paling signifikan terhadap gaya angkat pesawat. Rata-rata gaya angkat maksimum harian terjadi sekitar pukul 05.00 - 06.00 WIB dan minimum terjadi sekitar pukul 13.00 - 14.00 WIB. Gaya angkat terbesar bulanan terjadi pada bulan Januari dan terkecil pada bulan Agustus.

\section{Daftar Pustaka}

[1] Fadholi, A. "Studi Pengaruh Suhu Dan Tekanan Udara Terhadap Daya Angkat Pesawat Di Bandara S. Babullah Ternate." Jurnal Teori dan Aplikasi Fisika Vol.01 No. 02 Juli, 2013.

[2] Fadholi, A. "Pola Angin Permukaan di Bandara Depati Amir Pangkalpinang Periode Januari 2000 - Desember 2011". Jurnal Statistika Universitas Islam Bandung, Vol. 12 No. 1, 2012.

[3] Fadholi, A. "Pengaruh Suhu dan Tekanan Udara Terhadap Operasi Penerbangan di Bandara Depati Amir Pangkalpinang." Buletin Balai Besar Meteorologi dan Geofisika Wilayah II Ciputat. Vol. 3 No. 2, 2013.

[4] Sujarwo. Pengaruh Suhu udara Terhadap Daya Angkat Pesawat di Bandara Hasanuddin Makassar, Universitas Negeri Makassar, Makassar, 2006.

[5] Rosiydah. Studi Kasus Tinjauan Pengaruh Cuaca Terhadap Operasi Penerbangan,Khususnya Di Daerah Cengkareng. Skripsi Badan Diklat Meteorologi dan Geofisika, Jakarta, 2006.

[6] Utama, C. Pengaruh Suhu dan Tekanan Udara Terhadap Daya Angkat Pesawat di Bandara Hasanuddin Makassar, Skripsi Universitas Negeri Makassar.,Makassar, 2008. 
[7] Soeyitno \& Soeharsono. Meteorologi Penerbangan, Badan Diklat Meteorologi dan Geofisika, Jakarta, 1981.

[8] Murry L. Salby. Fundamentals of Atmospheric Physics, Academic Press, Elsevier Science, 1996.
[9] Soepangkat. Pengantar Meteorologi. Badan Diklat Meteorologi dan Geofisika, Jakarta, 1992.

Delta Virtual Airlines, Boeing 737-800

Operating Manual, 2013. 